\title{
Research in International Law
}

Under the Auspices of the Faculty of the Harvard Law School

\author{
I. Extradition \\ II. Jurisdiction with Respect to Crime \\ III. Law of Treaties
}

DRAFTS OF CONVENTIONS PREPARED FOR THE CODIFICATION OF INTERNATIONAL LAW

Parts I and II bound in this volume

Part III, with Index, bound separately

SUPPLEMENT TO THE

American Journal of International Law

Volume 29, 1935 
COPYRIGHT 1935

AMERICAN SOCIETY OF INTERNATIONAL LAW

WAGHINGTON, D. C.

PRINTED IN THE UNITED STATES OF AMERICA

AT THE RUMFORD PRESS, CONCORD, N. H. 


\section{RESEARCH IN INTERNATIONAL LAW}

UNder the Auspices of the Faculty of the

Harvard Law School

Director: Manley O. Hudson, Cambridge, Mass.

REPORTERS, 1932-1935

Extradition: CHARLES K. BURdICK

Jurisdiction with Respect to Crime: EDwIN D. DICKInson

Law of Treaties: JAMES W. GaRner

\section{EXECUTIVE COMMITTEE}

Joseph W. Bingham

George W. Wickersham, Chairman

EDWIN M. BorchaRd

George A. Finch

Richard W. Flournoy, JR.

Manley O. Hudson
PHILIP C. Jessup

Jesse S. Reeves

JAMES Brown ScotT

George Grafton Wilson

QUINCY WRIGHT

\section{ADVISORY COMMITTEE}

George W. Wickersham, Chairman

New York

Chandler P. Anderson

Washington

Joseph W. Bingham

Stanford University

EDWIN M. Borchard

Yale Law School

Clement L. Bouve

Washington

Philip Marshall Brown

Princeton

Charles K. Burdick

Cornell Law School

Charles C. Burlingham

New York

Joseph P. Chamberlain

Columbia University
Frederic R. Coudert

New York

Willtam Denman

San Francisco

William C. Dennis

Earlham College

Edwin D. Dickinson

University of California

Frederick S. DunN

Johns Hopkins University

Clyme Eagleton

New York University

Charles G. Fenwick

Bryn Mawr College

George A. Finch

Washington

Richard W. Flournoy, JR.

Washington 


\section{GENERAL INTRODUCTION}

\section{Previous Work of the Research in International Law}

The Research in International Law was organized under the auspices of the Faculty of the Harvard Law School in 1927 and 1928, for the purpose of preparing a draft of an international convention on each of the subjects which had then been placed on the agenda of the First Conference for the Codification of International Law.

In 1929 , the Research published a volume ${ }^{1}$ containing the following draft conventions, with comments:

(1) Nationality, with Richard W. Flournoy, Jr., of the Department of State, as Reporter;

(2) Responsibility of States for Injuries to Foreigners, with Edwin M. Borchard, of the Yale Law School, as Reporter; and

(3) Territorial Waters, with George Grafton Wilson, of Harvard University, as Reporter.

In 1930, the Research published, through the Carnegie Endowment for International Peace, A Collection of Nationality Laws of Various Countries, edited by Richard W. Flournoy, Jr., and Manley O. Hudson.

In a second phase of its work, from 1929 to 1932, the Research published a volume ${ }^{2}$ containing the following draft conventions, with comments:

(1) Diplomatic Privileges and Immunities, with Jesse S. Reeves, of the University of Michigan, as Reporter;

(2) Legal Position and Functions of Consuls, with Quincy Wright, of the University of Chicago, as Reporter;

(3) Competence of Courts in regard to Foreign States, with Philip C. Jessup, of Columbia University, as Reporter; and

(4) Piracy, with Joseph W. Bingham, of Stanford University, as Reporter.

The 1932 volume also contained $A$ Collection of Piracy Laws of Various Countries, edited by Stanley Morrison, of Stanford University.

In 1933, the Research published, through the Carnegie Endowment for International Peace, A Collection of the Diplomatic and Consular Laws and Regulations of Various Countries (in two volumes), edited by A. H. Feller and Manley O. Hudson.

\section{Third Phase of the Work of the Research in International Law}

In 1932, the Advisory Committee of the Research in International Law decided to continue its work for a third phase, from 1932 to 1935 , and to

\footnotetext{
1 Republished, with the same pagination, as a special supplement to Volume 23 of the American Journal of International Law.

2 Republished, with the same pagination, as a supplement to Volume 26 of the American Journal of International Law.
} 
deal with three additional subjects. During this period, the membership of the Advisory Committee has been as follows:

George W. Wickersham, Chairman, New York City.

President of the American Law Institute. Formerly Attorney General of the United States.

Chandler P. Anderson, Washington, D. C.

Commissioner of the United States, German-American Mixed Claims Commission. Formerly Counsellor of the Department of State; United States Arbitrator, British-American Pecuniary Claims Arbitration, United States-Norway Shipping Claims Arbitration.

Joseph W. Bingham, Stanford University, California.

Professor of Law, Stanford University.

Edwin M. Borchard, New Haven, Connecticut.

Professor of Law, Yale University; Associate of the Institut de Droit International.

Clement L. Bouve, Washington, D. C.

Formerly Agent of the United States, General and Special Claims

Commissions, United States and Mexico; Commissioner of the United States, United States and Panama Mixed Commission.

Philip Marshall Brown, Princeton, New Jersey.

Member of the Institut de Droit International. Formerly Professor of International Law, Princeton University.

Charles K. Burdick, Ithaca, New York.

Dean of the Cornell Law School.

Charles C. Burlingham, New York City.

Formerly President of the Bar Association of the City of New York.

Joseph P. Chamberlain, New York City.

Professor of Public Law, Columbia University.

Frederic R. Coudert, New York City.

Member of the New York Bar; Associate of the Institut de Droit International.

William Denman, San Francisco.

Judge of the United States Circuit Court, Ninth Circuit. Formerly Chairman of United States Shipping Board; President of the Emergency Fleet Corporation.

Wiluram C. Dennis, Richmond, Indiana.

President of Earlham College. Formerly Agent of the United States in various international arbitrations; legal adviser to the Chinese Government at Peking.

Edwin D. Dickinson, Berkeley, California.

Professor of International Law, University of California. 
Frederick S. Dunn, Baltimore, Maryland.

Creswell Lecturer on International Law, Johns Hopkins University.

Clyde Eagleton, New York City.

Professor of Government, New York University.

Charles G. Fenwick, Bryn Mawr, Pennsylvania.

Professor of Political Science, Bryn Mawr College.

George A. Finch, Washington, D. C.

Managing Editor, American Journal of International Law; Assistant Director of the Division of International Law, Carnegie Endowment for International Peace. Formerly Assistant Legal Adviser to the American Commission to Negotiate Peace at Paris.

Richard W. Flournoy, JR., Washington, D. C.

Assistant to the Legal Adviser, Department of State; Professor of International Law, National University.

RAYMond B. Fosdick, New York City.

Member of the New York Bar. Formerly Under-Secretary-General of the League of Nations.

Henry S. Fraser, Syracuse, New York.

Member of the New York Bar.

James W. Garner, Urbana, Illinois.

Professor of Political Science, University of Illinois; President of the Institut International de Droit Public.

Green H. Hackworth, Washington, D. C.

Legal Adviser, Department of State.

Learned Hand, New York City.

Judge of the United States Circuit Court, second circuit.

Frank E. Hinckley, San Francisco.

Member of the San Francisco Bar. Formerly Lecturer on International Law, School of Jurisprudence, University of California;

District Attorney, United States Court for China.

Manley O. Hudson, Cambridge, Mass.

Bemis Professor of International Law, Harvard Law School, member of the Permanent Court of Arbitration.

Charles Cheney Hyde, New York City.

Hamilton Fish Professor of International Law and Diplomacy, Columbia University; Associate of the Institut de Droit International. Formerly Solicitor for the Department of State.

Phinip C. Jessup, New York City.

Associate Professor of International Law, Columbia University.

Howard Thayer Kingsbury, New York City.

Member of the New York Bar.

Arthur K. KunN, New York City.

Member of the New York Bar. Associate of the Institut de Droit

International. 
William Draper Lewis, Philadelphia, Pennsylvania.

Director of the American Law Institute. Formerly Professor of Law, University of Pennsylvania.

John V. A. MacMurray, Riga, Latvia.

United States Minister to Estonia, Latvia and Lithuania. Formerly United States Minister to China.

Hunter Miller, Washington, D. C.

Historical Adviser, Department of State. Formerly Legal Adviser to the American Commission to Negotiate Peace at Paris.

Roland S. Morris, Philadelphia, Pennsylvania.

Professor of International Law, University of Pennsylvania. Formerly United States Ambassador to Japan.

Stanley Morrison, Stanford University, California.

Professor of Law, Stanford University.

Pitman B. Potrer, Geneva, Switzerland.

Institut Universitaire de Hautes Etudes Internationales, University of Geneva.

Jackson H. Ralston, Palo Alto, California. Formerly Umpire, Italy-Venezuela Claims Commission.

Jesse S. ReEves, Ann Arbor, Michigan.

William W. Cook Professor of American Institutions, University of Michigan; Associate of the Institut de Droit International. Formerly President of the American Political Science Association.

Elinu Root, New York City.

Honorary member of the Institut de Droit International; member of the Permanent Court of Arbitration. Formerly Secretary of State; President of the American Society of International Law.

James Brown Scotr, Washington, D. C.

President of the American Society of International Law; Director of the Division of International Law, Carnegie Endowment for International Peace. Formerly Solicitor for the Department of State; Legal Adviser to the American Commission to Negotiate Peace at Paris; President of the Institut de Droit International.

Daniel C. Stanwood, Brunswick, Maine.

Professor of International Law, Bowdoin College.

Ellery C. Stoweld, Washington, D. C.

Professor of International Law, American University.

Van Viechten Veeder, New York City.

President of the Maritime Law Association of the United States.

Formerly Judge of the United States District Court.

Thomas Raeburn White, Philadelphia, Pennsylvania.

Member of the Pennsylvania Bar.

John B. Whitron, Princeton, New Jersey.

Professor of International Law, Princeton University. 
George Grafton Wilson, Cambridge, Massachusetts.

Professor of International Law, Harvard University; Editor-inChief of the American Journal of International Law; Member of the Institut de Droit International.

John M. Woolsey, New York City.

Judge of the United States District Court.

Lester H. Woolsey, Washington, D. C.

Member of the District of Columbia Bar. Formerly Solicitor for the Department of State.

QUINCY WrIGHT, Chicago, Illinois.

Professor of International Law, University of Chicago.

The Advisory Committee has had the following meetings since the beginning of the work of the Research:

(1) Cambridge: January 7, 1928.

(2) Washington: April 28, 1928.

(3) Cambridge: October 5, 6, 1928.

(4) Cambridge: February 22, 23, 24, 1929.

(5) Cambridge: February 20, 21, 22, 1931.

(6) Cambridge: February 19, 20, 21, 1932.

(7) Cambridge: February 22, 23, 24, 1934.

(8) Cambridge: February 21, 22, 23, 1935.

In 1932, the Executive Committee of the Research invited Mr. Charles K. Burdick, Dean of the Cornell Law School, to act as Reporter on the Law of Extradition; Mr. Edwin D. Dickinson, of the School of Jurisprudence of the University of California, to act as Reporter on Jurisdiction with respect to Crime; and Mr. James W. Garner, of the University of Illinois, to act as Reporter on the Law of Treaties.

(1) Law of Extradition. In 1925, this subject was studied by the League of Nations Committee of Experts, and a subcommittee consisting of Professors J. L. Brierly and Charles de Visscher was appointed to report upon it. Having before it the report of this subcommittee, ${ }^{3}$ the Committee of Experts reached the conclusion on January 29, 1926, that the difficulties in the way of a general agreement on this subject were too great for their solution to be realizable in the near future, though such solution "appeared very desirable." In spite of this view taken by the Committee of Experts, the Executive Committee of the Research was of the opinion that the subject should be explored. It is to be noted that two multipartite conventions on extradition have recently been opened to signature, at Montevideo on December 26, 1933, ${ }^{4}$ and at Guatemala City on April 12, 1934.

The Reporter on the Law of Extradition, Mr. Charles K. Burdick, has

s League of Nations Document C.51.M.28.1926.V; 20 American Journal of International Law (Special Supplement, 1926), p. 243.

4 The Montevideo Convention came into force for the United States and the Dominican Republic on Jan. 25, 1934. 
been assisted by Mr. V. G. Terentieff, Mr. Lucien Tharaud, and by the following advisers:

JOSEPH R. BAKER

Edwin M. Borchard

Herbert W. Briggs

Francis Deák

Edwin D. Dickinson

A. H. FeLLeR

George A. Finch

Henry S. Fraser
Green H. Hackworth

Charles C. Hyde

Philip C. Jessup

Jesse S. Reeves

Daniel C. Stanwood

George W. Wickersham

George Grafton Wilson

Lester H. WOOLSEY

Meetings of the Reporter and advisers on the Law of Extradition have been held as follows:

New York: January 20, 21, 22, 1933

Ithaca: June 1, 2, 3, 1933

Ithaca: December 1, 2, 1933

Ithaca: May 13, 14, 1934

New York: November 30, December 1, 2, 1934

(2) Jurisdiction with respect to Crime. In 1925, the League of Nations Committee of Experts for the Progressive Codification of International Law studied the subject of "Criminal Competence of States in Regard to Offences Committed Outside Their Territories," and appointed a subcommittee consisting of Professor J. L. Brierly and Professor Charles de Visscher to report upon it. Having before it the report of this subcommittee, ${ }^{5}$ the Committee of Experts reached the conclusion on January 29, 1926, that "international regulation of these questions by way of a general convention, although desirable, would encounter grave political and other obstacles." 8 In spite of this fact, the Executive Committee of the Research was of the opinion that the subject should be explored.

The Reporter on Jurisdiction with respect to Crime, Mr. Edwin D. Dickinson, has been assisted by Mr. William W. Bishop, Jr., as Assistant Reporter, by Mr. Benjamin Akzin, Mr. Lawrence Preuss, and by the following advisers:

JosePh W. BinghaM

EDWIN M. Borchard

Charles K. Burdick

JohN U. CALKINS

William Denman

A. H. Feller

Farnham P. Griffiths

Frank E. HinckLey

Philis C. Jessup

Alexander M. KIDD

Arthur K. KuHN
Stephen I. Langmaid

Albert Levitit

JAMES P. MCBAINE

Dudley O. MCGovney

ORRIN K. McMURRAY

Stanley Morrison

Max Radin

Jesse S. Reeves

Chester G. Vernier

August Vollmer

- League of Nations Document C.50.M.27.1926.V; 20 American Journal of International Law (Special Supplement, 1926), p. 253. 
Meetings of the Reporter and advisers on Jurisdiction with respect to Crime have been held as follows:

Ann Arbor: December 16, 17, 1932

Berkeley: December 21, 22, 23, 1933

Berkeley: December 20, 21, 22, 1934

(3) The Law of Treaties. In 1925, the League of Nations Committee of Experts for the Progressive Codification of International Law studied the subject of "Procedure of International Conferences and Procedure for the Conclusion and Drafting of Treaties," and appointed a subcommittee consisting of MM. Mastny and Rundstein to report upon it. With the report of this subcommittee before it, ${ }^{7}$ the Committee of Experts placed the subject on its provisional list and sought the comments of Governments. ${ }^{8}$ On April 2, 1927, the Committee of Experts reached the conclusion that the subject was "sufficiently ripe" for codification, ${ }^{9}$ but it suggested ${ }^{10}$ a special procedure for this subject. When its report came before the Council and Assembly of the League of Nations, these bodies were content to have the subject investigated by the Secretariat."1 On February 20, 1928, a convention on "Treaties" was adopted at Havana by the Seventh International Conference of American States, ${ }^{12}$ but it has not been ratified by all the States represented at that conference. In view of this situation, the Executive Committee of the Research was of the opinion that the subject should be explored.

The Reporter on the Law of Treaties, Mr. James W. Garner, has been assisted by Mr. Valentine Jobst, as Assistant Reporter, and by the following advisers:

Benjamin Akzin
Charles M. Barnes
Clarence A. Berdahl
Clyde Eagleton
John A. Fairlie
Richard W. Flournoy, Jr.
Green H. Hackworth
Chesney Hrll
Charles C. Hyde

Philip C. Jessur

Howard T. KINGSBURY

Hunter MILLER

Jesse S. ReEves

JoHN B. WhitToN

George W. Wickersham

George G. WILsoN

Lester H. WOOLSEY

QUINCY WRIGHT

Meetings of the Reporter and advisers have been held as follows:

New York: November 18, 19, 20, 1932

\footnotetext{
${ }^{7}$ League of Nations Document C.47.M.24.1926.V; 20 American Journal of International Law (Special Supplement, 1926), p. 264.

8 Ibid. For the comments of Governments, see Document C.196.M.70.1927.V.

${ }^{9}$ League of Nations Document C.196.M.70.1927.V., p. 7.

${ }^{10}$ Id., C.198.M.72.1927.V; 22 American Journal of International Law (Special Supplement, 1928), p. 43.

i1 League of Nations Official Journal, 1927, p. 754; Records of Eighth Assembly, Plenary, p. 203.

134 Hudson, International Legislation (1931), p. 2378.
} 
Washington: April 24, 25, 1933

Urbana: June 11, 12, 13, 1933

Urbana: December 17, 18, 1933

Washington: April 24, 25, 26, 1934

Urbana: September 30, October 1, 1934

Urbana: December 15, 16, 1934

In the three draft conventions published in this volume, explanatory titles have been given to the various articles; it will of course be understood that these titles are simply labels of convenience, designed to assist the reader, and that they are not intended to serve as guides to the interpretation of the text.

\section{Responsibility for the Drafts}

The drafts which are now published as the results of the third phase of the work of the Research, have been made with the object of stating the collective views of a group of Americans specially interested in the development of international law, concerning the subjects which may be considered in connection with the codification of international law. The drafts represent the result of the work of American jurists and scholars after thorough consultation, and as such it is hoped that they may merit the attention of persons interested in the codification of international law. The proposals contained in the drafts, and the statements in the comments, are not to be taken to represent the individual views of any of the persons who have taken part in their preparation.

The preparation of the draft conventions and comments has been completed within the limits of a rigorous time-schedule, by men already burdened with exacting duties; and these facts should be borne in mind in any appraisal of the work done.

The Research is wholly unofficial, and the drafts must not be taken as in any way representing the views of the Government of the United States.

\section{The Prospect for Codification}

The first Conference for the Codification of International Law, which met at The Hague from March 13 to April 13, 1930, achieved a very limited success. On September 1, 1934, none of the instruments opened to signature at the conference had been brought into force, but they had been acted upon as follows:

(1) Convention on certain questions relating to Confict of Nationality Laws. Ratifications or accessions deposited at Geneva by Brazil, Great Britain, Canada, Monaco, Norway, Poland and Sweden.

(2) Protocol relating to Military Obligations in Certain Cases of Double Nationality.

Ratifications or accessions deposited at Geneva by United States of America, Brazil, Great Britain, India and Sweden. 
(3) Protocol relating to a Certain Case of Statelessness.

Ratifications or accessions deposited at Geneva by Brazil, Great Britain, India and Poland.

(4) Special Protocol concerning Statelessness.

Ratifications or accessions deposited at Geneva by Brazil, Great Britain and India.

The 1930 Hague Conference adopted the following resolution concerning the continuation of the work of codification: ${ }^{13}$

The Conference

Calls the attention of the League of Nations to the necessity of preparing the work of the next conference for the codification of international law a sufficient time in advance to enable the discussion to be carried on with the necessary rapidity and in the light of the information which is essential.

For this purpose the Conference would consider it desirable that the preparatory work should be organised on the following basis:

1. The Committee entrusted with the task of selecting a certain number of subjects suitable for codification by convention might draw up a report indicating briefly and clearly the reasons why it appears possible and desirable to conclude international agreements on the subjects selected. This report should be sent to the Governments for their opinion. The Council of the League of Nations might then draw up the list of the subjects to be studied, having regard to the opinions expressed by the Governments.

2. An appropriate body might be given the task of drawing up, in the light of all the data furnished by legal science, and actual practice, a draft convention upon each question selected for study.

3 . The draft conventions should be communicated to the Governments with a request for their observations upon the essential points. The Council would endeavour to obtain replies from as large a number of Governments as possible.

4. The replies so received should be communicated to all the Governments with a request both for their opinion as to the desirability of placing such draft conventions on the agenda of a conference and also for any fresh observations which might be suggested to them by the replies of the other Governments upon the drafts.

5. The Council might then place on the programme of the Conference such subjects as were formally approved by a very large majority of the Powers which would take part therein.

On September 26, 1931, the Twelfth Assembly of the League of Nations adopted the following resolution: ${ }^{14}$

The Assembly recalls that the resolution of September 22nd, 1924, emphasised the progressive character of the codification of international law which should be undertaken, and, in view of the recommendations of the First Conference for the Codification of International Law held at The Hague in 1930, it decides to continue the work of codification with the object of drawing up conventions which will place the relations of States on a legal and secure basis without jeopardising the customary

${ }^{13} 26$ American Journal of International Law (1932), p. $137 . \quad$ 14 Id., p. 141. 
international law which should result progressively from the practice of States and the development of international jurisprudence.

To this end, the Assembly decides to establish the following procedure for the future, except in so far as, in particular cases, special resolutions provide to the contrary:

1. Any State or group of States, whether Members of the League or not, may propose to the Assembly a subject or subjects with respect to which codification by international conventions should be undertaken. Such proposals, together with a memorandum containing the necessary explanatory matter, should be sent, before March 1st, to the SecretaryGeneral, in order that he may communicate them to Governments and insert them in the agenda of the Assembly.

2. Any such proposals will be considered by the Assembly, which will decide whether the subjects proposed appear prima facie suitable for codification.

3. If the investigation of a proposed subject is approved by the Assembly and if no existing organ of the League is competent to deal with it, the Assembly will request the Council to set up a committee of experts, which will be asked with the assistance of the Secretary-General of the League of Nations to make the necessary enquiries and to prepare a draft convention on the subject, to be reported to the Council with an explanatory statement.

4. The Council will transmit such report to the Assembly, which will then decide whether the subject is provisionally to be retained as a subject for codification. If this is decided affirmatively, the Assembly will ask the Secretary-General to transmit the said report to the Governments of the Members of the League and non-member States for their comments.

5. The committee of experts, if it considers it desirable to do so, will revise the draft in the light of the comments made by the Governments.

If the committee of experts revises the draft, the revised draft will be submitted to the Governments for their comments and, together with the comments received, will be transmitted to the Assembly, which will then decide finally whether any further action should be taken in the matter and, if so, if the draft should be submitted to a codification conference.

If the committee does not see any reason to revise the draft, it will be transmitted, together with the comments of the Governments, to the Assembly, which will then decide finally whether any further action should be taken and, if so, if the draft should be submitted to a codification conference.

The Assembly recommends:

(1) That, in relation with the further work in connection with the codification of international law, the international and national scientific institutes should collaborate in the work undertaken by the League of Nations;

(2) That the work of codification undertaken by the League of $\mathrm{Na}$ tions should be carried on in concert with the conferences of the American States.

This resolution has halted, for the time being, the formal efforts of the League of Nations directed toward codification. No government has since made any suggestion calling for the resumption of these efforts. 
Meanwhile, however, the Seventh International Conference of American States, meeting at Montevideo, adopted the following resolution on December $26,1933:^{15}$

The Seventh International Conference of American States:

CoNSIDERING: That the codification of international law must be gradual and progressive, it being a vain illusion to think for a long time of the possibility of carrying it out completely;

That, without prejudice to the work already accomplished in the International Conferences of American States, the task of gradual and progressive codification must be done by jurists specialized in international law, who should be provided in the decisive meetings with plenipotentiary powers to sign treaties;

That it is indispensable, if it is desired to do practical work with actual results, to seek the conjunction of the juridical viewpoints, theoretical and universal in essence, with the political viewpoints, positive and localistic by nature;

That in this connection the necessity of coordinating this work with the work of codification being done by the League of Nations must be taken into account as far as possible, since international law tends to universalize its rules as the interdependence of the civilized community becomes more and more confirmed and consolidated;

That to this end it is necessary to create a special organization for the preparatory work with the purpose of fixing the basic elements for the gradual and progressive elaboration of international law;

\section{RESOLVES:}

1. There is maintained the International Commission of Jurisconsults, created by the Third International American Conference, with the mission of bringing about the gradual and progressive codification of international public law and international private law. This Commission will be composed of jurists named by each government.

2. Each government of the American republics will create respectively a national commission of codification of international law. This Conference considers that these commissions shall be made up of qualified officials or ex-officials from the respective Foreign Offices, and by professors or jurists who are specialists in international law. Each commission shall act through the channel of the respective Foreign Office.

3. There shall be created a Commission of Experts with the duty of organizing with a preparatory character, the work of codification. This Commission shall be composed of seven jurists chosen as follows:

Each of the twenty-one governments shall send to the Pan American Union a list of not to exceed five persons having the same qualifications as the members of the national commissions provided for in Article 2 hereof. The Pan American Union shall transmit all these different lists to the governments.

Once the definite lists are made up, each government shall designate from said lists seven persons, of whom only two shall be nationals, whom they desire to constitute the Commission of Experts, communicating its choice to the Pan American Union.

If, after three months a government has not submitted its list of

${ }^{10}$ Final Act of the Seventh International Conference of American States, p. 108. 
candidates, then after a month's delay the Pan American Union will proceed to form the final list with the names received to date. The seven persons who obtain the highest number of votes shall constitute the first Commission of Experts. In case of a tie the Governing Board shall decide it by lot. It is understood, however, that the Commission of Experts, however chosen or elected, must always contain at least one person representing each of the two great systems of jurisprudence of this hemisphere.

If the name of no such person is found among the first seven persons having the highest number of votes, then that person having the highest number of votes of any person listed by the government or governments having the particular system of jurisprudence not represented among those having the seven highest votes, shall be made a member of the commission in the place of that particular person of the seven who had the least number of votes.

4. The persons elected pursuant to the foregoing provisions shall hold office until the end of the first session of the International Commission of Jurisconsults.

The International Commission of Jurisconsults shall at its first meeting determine the organization, functions, duties, and terms of office of the Commission of Experts and of its members. Until such determination is made the Commission shall have such organization, functions, and duties as are hereinafter provided.

This Commission of Experts shall be a subcommittee of the International Commission of Jurisconsults. The members of this subcommittee shall be ex officio members of the International Commission of Jurisconsults. When that International Commission is in session, the members of the subcommittee shall be considered as members thereof and of the delegation named by the country of which they are nationals.

5. There shall be created in the Pan American Union a general secretariat charged with the files and correspondence of the codifying bodies. With this in view the Pan American Union will establish a juridical section of a purely administrative character.

6. Both the Commission of Experts as well as the separate local commissions of codification should take into account, in so far as it may be convenient, the suggestions and projects which other institutions may submit for its consideration.

7. The first meeting of the Commission of Experts will take place as soon as possible at the Pan American Union in Washington, where there shall have been organized a juridical section referred to in Article 5.

The subsequent meetings of the Commission of Experts shall be annual and will take place in the various cities of America which the Commission itself shall determine at the proper time.

8. The Commission of Experts will proceed to examine all the problems of private and public international law and will make a list of those matters which it considers susceptible of codification. With respect to each point it will draw up a questionnaire which it will submit to the consideration of all the national commissions of codification.

Each commission will study thoroughly the topics contained in the questionnaire and within a reasonable time will give its views thereon, returning the reply through the respective Foreign Offices to the juridical section of the Pan American Union.

This procedure does not prevent an exchange of ideas on one or more 
topics between the national commissions themselves, it being on the contrary even desirable that this method be adopted.

9. It shall be the special duty of the juridical section of the Pan American Union to expedite whenever necessary the prompt submission of the views solicited.

Once the replies and observations have been received from the Foreign Offices, the division shall notify the Governing Board of the Pan American Union in order that it may arrange a meeting of the Commission of Experts which shall be held at the place which may have been decided upon at its previous meeting.

10. The Commission of Experts so convoked shall undertake a thorough study of the replies and observations received and shall proceed to classify them according to topics or concrete points in two categories:

(1) Those which are susceptible of codification because there is a harmony of opinions which permits the formulation of concrete bases of discussion;

(2) Those which do not fulfill these conditions.

When the classification is made, the Commission of Experts shall coordinate the various points of view and shall form concrete bases of discussion for the International Commission of Jurisconsults. The antecedents thus prepared by the Commission of Experts and all the documents transmitted by the governments shall serve as a basis for the work of the International Commission of Jurisconsults.

The Commission of Experts, when it may have prepared a reasonable number of projects or declarations such as to justify a meeting of the International Commission of Jurisconsults, will so notify the Governing Board of the Pan American Union in order that the latter may call that Commission together.

11. The next meeting of the International Commission of Jurisconsults will be held in the city of Rio de Janeiro and the following meetings in the places arranged by the Commission itself.

12. The members of the International Commission of Jurisconsults shall have the character of plenipotentiary delegates.

13. The organs of codification shall not, in the work of juridical organization, alter the fundamental principles of positive International Law already established by Convention between the American States.

14. The expenses arising out of the attendance of the delegates or of experts at the meetings provided in the previous articles shall be for the account of the government whose national is concerned.

This resolution represents a decided departure from the methods heretofore followed by the International Conference of American States. On January 1,1935 , only 13 of the 21 Governments had sent in the lists of candidates as provided in sub-paragraph 1 of section 3 of the resolution, and the Pan American Union had not proceeded to form the final list as provided in sub-paragraph 3. Hence, the members of the Commission of Experts have not yet been elected.

MaNLey O. Hudson

Director

April 1, 1935. 


\section{PART I \\ EXTRADITION}

\section{REPORTER}

Charles K. Burdick, Cornell Law'School

RESEARCH ASSISTANTS

V. G. Terentieff, Cornell University

Lucien Tharaud, New York City

\section{ADVISERS}

Joseph R. BAKeR, Department of State Edwin M. Borchard, Yale Law School Herbert W. Briggs, Cornell University Francis Deák, Columbia Law School EDwin D. Dickinson, University of California A. H. FeLLer, Department of Justice George A. Finch, Washington Henry S. Fraser, Syracuse Green H. Hackworth, Department of State Chardes Cheney Hyde, Columbia Law School Phirip C. Jessup, Columbia Law School Jesse S. Reeves, University of Michigan Daniel C. Stanwood, Bowdoin College George W. Wrckersham, New York George Grafton Wilson, Harvard University Lester H. Woolsey, Washington 


\section{CONTENTS}

Draft Convention on Extradition $\ldots \ldots \ldots \ldots \ldots \ldots \ldots \ldots \ldots$

Text with Comment

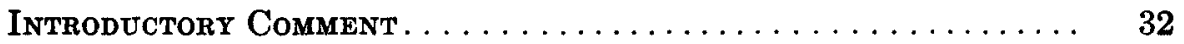

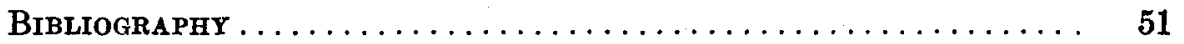

Part I. Use of Terms

Article 1. Use of Terms..................... 66

Part II. ACts

Antiche 2. Extraditable Acts................... 72

Article 3. Place of Commission of Extraditable Acts . . . . . . . . 86

Article 4. Lapse of Time. . . . . . . . . . . . . . . . . . 99

Article 5. Political Offenses....................... 107

Article 6. Military Offenses.................... 119

Part III. Persons

ARticLE 7. Nationals of Requested State. . . . . . . . . . . 123

Article 8. Conflicting Requisitions................. 137

Article 9. Non Bis in Idem . . . . . . . . . . . . . . . . . . 144

Article 10. Pending Prosecution for the Same Acts.... . . . . . . . 148

Article 11. Postponed or Conditional Extradition ........... 151

Part IV. Extradition Procedure

Article 12. The Requisition and Supporting Documents. . . . . 158

ARTICLE 13. Supplementary Documents.............. 165

Article 14. Apprehension and Detention of Person Claimed . . . 166

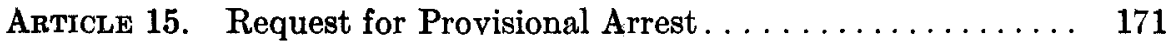

Article 16. Provisional Arrest. . . . . . . . . . . . . . . 179

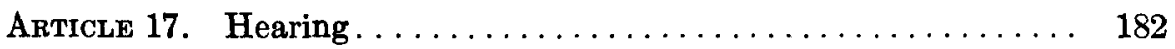

Antiche 18. Effect of Judicial Determination............ 200

Article 19. Language to be Used and Translations . . . . . . . . 201

Anticle 20. Arrangement for Extradition.............. 204

Anticle 21. Reimbursement of Requested State........... 206

Article 22. Transit Through Territory of Third State........ 208

Part V. Limitations upon the Requesting State

Artiche 23. Trial, Punishment and Surrender of Extradited Person. . 213 
Article 24. Delivery and Return of Property Requested...... 21؟

\section{Part VII. General Provisions}

Article 25. Reservations in Schedule A and Declaration in Sched-

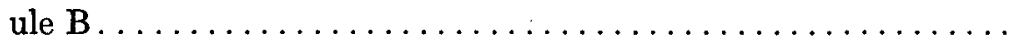

Article 26. Declaration as to Application of Convention to Certain Territories. . . . . . . . . . . . . . . . . . . . . . . . . . . 222

Article 27. Other Extradition Agreements............... 222

Article 28. Settlement of Disputes............... 22

\section{Schedule A}

Reservation Number One. Capital Punishment............. 228

Reservation Number Two. Fiscal Offenses ............. $22 \varepsilon$

Reservation Number Three. Non-Extradition of Nationals with

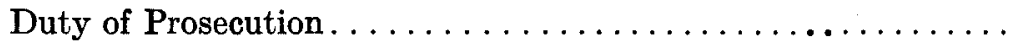

Reservation Number Four. Non-Extradition of Nationals with-

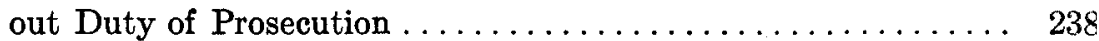

Reservation Number Five. Prima Facie Case ........... $23 \varepsilon$

Reservation Number Six. Prima Facie Case in Extradition of Nationals................................. 239

Reservation Number Seven. Refusal of Transit for Political and Military Offenses ...................... 23s

\section{Schedule B}

Declaration as to Political and Military Offenses........... 24C

\section{Appendices}

Appendix I. Chronological List of Extradition Treaties..... Appendix II (A). Extraditable Offenses in United States Treaties 1900-1930

List of Treaties

List of Offenses.

Appendix II (B). Extraditable Offenses in Treaties Concluded by States Other than the United States

List of Treaties. . . . . . . . . . . . . . . . . . . . . . $25 \varepsilon$

List of Offenses. . . . . . . . . . . . . .

Appendix III. Multipartite Extradition Conventions

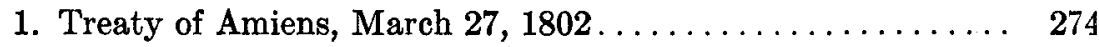

2. Treaty of International Penal Law. Montevideo, Jan. 23, 1889 . 
PAGE

3. Treaty for the Extradition of Criminals and for Protection

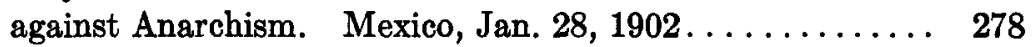

4. Agreement on Extradition. Caracas, July 18, 1911 . . . . . 282

5. Bustamante Code. Habana, Feb. 20, 1928 ........... 285

6. Convention on Extradition. Montevideo, Dec. 26, 1933... . 289

7. Central American Extradition Convention. Guatemala, April 12,1934 .

293

Appendix IV. Drafts and Projects

1. Field's Outlines of an International Code, $1876 \ldots \ldots \ldots \ldots$

2. Resolution adopted by Institute of International Law, Oxford,

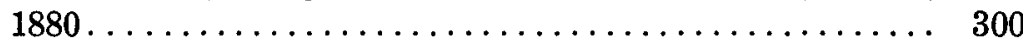

3. Draft of International Commission of Jurists, Rio de Janeiro,

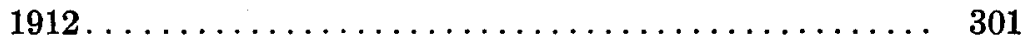

4. Travers' Project for an Extradition Treaty, 1922 . . . . . . . 305

5. Draft approved by International Law Association, 1928. . . . . 307

6. Model Draft of Sub-Commission of International Penal and Prison Commission, 1931.................. 309

Appendix V. Typical Bipartite Treaties of Recent Date

1. United States-Great Britain, $1931 \ldots \ldots \ldots \ldots \ldots \ldots \ldots \ldots . \ldots \ldots$

2. United States-Austria, $1930 \ldots \ldots \ldots \ldots \ldots \ldots \ldots \ldots \ldots . \ldots \ldots$

3. Germany-Turkey, $1930 \ldots \ldots \ldots \ldots \ldots \ldots \ldots \ldots \ldots \ldots \ldots$

4. Brazil-Italy, $1931 \ldots \ldots \ldots \ldots \ldots \ldots \ldots \ldots \ldots \ldots \ldots \ldots . . \ldots 29$

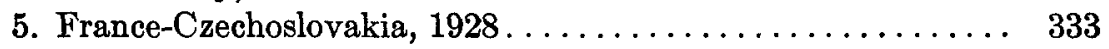

6. Belgium-Poland, $1931 \ldots \ldots \ldots \ldots \ldots \ldots \ldots \ldots \ldots \ldots \ldots \ldots$

7. Colombia-Panama, $1927 \ldots \ldots \ldots \ldots \ldots \ldots \ldots \ldots \ldots \ldots$

8. Finland-Netherlands, $1933 \ldots \ldots \ldots \ldots \ldots \ldots \ldots \ldots \ldots$

Appendix VI. Selected Extradition Statutes

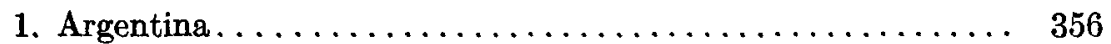

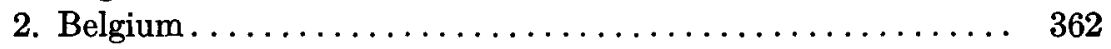

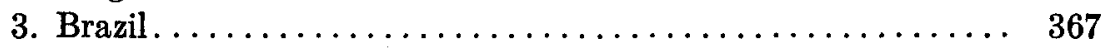

4. Canada. . . . ........................ 369

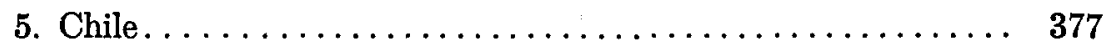

6. France.......................... 380

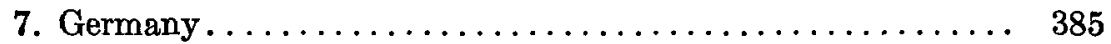

8. Great Britain . . . . . . . . . . . . . . . . . . 392

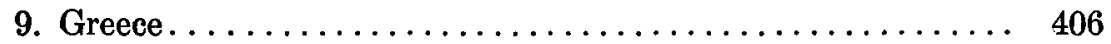

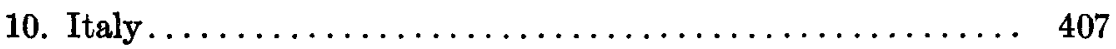

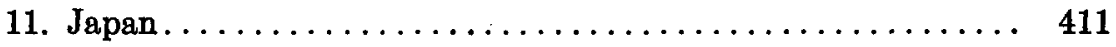

12. Sweden ........................... 414

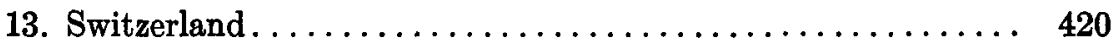

14. Turkey......................... 427

15. United States. . . . . . . . . . . . . . . . . 428 